\title{
A systematic review of tetanus in individuals with previous tetanus toxoid immunization
}

\author{
Hopkins $\mathrm{JP}^{1,2 *}$, Riddle $\mathrm{C}^{3}$, Hollidge $\mathrm{M}^{3}$, Wilson $\mathrm{SE}^{4,5}$ \\ ${ }^{1}$ Niagara Region Public Health, Thorold, Ontario \\ ${ }^{2}$ Department of Clinical Epidemiology and Biostatistics, McMaster University, Hamilton, Ontario \\ ${ }^{3}$ Niagara Health System, St. Catharines, Ontario \\ ${ }^{4}$ Public Health Ontario, Toronto, Ontario \\ ${ }^{5}$ Dalla Lana School of Public Health, University of Toronto, Toronto, Ontario \\ *Corresponding author: Jessica.hopkins@niagararegion.ca
}

\section{Abstract}

Objectives: To assess the characteristics of tetanus in previously immunized individuals.

Methods: A systematic literature search was undertaken using Ovid MEDLINE(R) and EMBASE databases for articles published between 1946 and September 3, 2013. The search strategy was developed using MESH terms for "tetanus", "immunization" and "vaccination". Inclusion criteria were articles in English or French that described at least one case of tetanus, immunization history and/or the results of anti-tetanus antibodies. Articles were reviewed for relevant references.

Results: 51 unique articles published from1946-2013 were included in the review. The articles described 359 cases of clinical tetanus in individuals with prior receipt of one or more doses of tetanus toxoid vaccine and/or levels of tetanus antibody titres generally considered protective. Of the 210 cases that reported patient status at discharge, $180(85.7 \%)$ survived with only three cases reporting residual deficits.

Conclusion: Tetanus spores are ubiquitous and this report clearly documents that tetanus cases can occur in individuals previously immunized with tetanus toxoid vaccine. Clinicians should not rule out tetanus when clinical symptoms suggest it, regardless of the vaccination history. When treated, the prognosis for tetanus is good. Further research is needed to assess the incidence of tetanus in partially- and fully-immunized populations and determine whether this is due to waning immunity of vaccine failure.

\section{Introduction}

A previously healthy 22 year-old man presented to an emergency department in Ontario, Canada with symptoms of spasm and trismus consistent with tetanus. Twenty-seven days prior to presentation, he reported a minor injury to the left great toe that appeared to form an abscess. He lanced the abscess himself, but the wound worsened whereupon he sought medical treatment. Medical treatment consisted of antibiotics followed by systemic steroids for a suspected allergic reaction to the antibiotics. Past medical history revealed five documented and appropriately spaced doses of tetanus toxoid-containing vaccine: Diphtheria, tetanus, pertussis (DTP) at 2, 4 and 6 months, Diphtheria, tetanus, acellular pertussis, inactivated polio (DTaP-IPV) at 18 months and Tetanus, diphtheria (reduced), acellular pertussis (reduced) (Tdap) at 14 years of age, nine years previously. There was no documentation of a pre-school booster typically given at 4-6 years. No additional tetanus-containing vaccine was given when he initially sought medical treatment. At the hospital, the patient was treated with tetanus immune globulin, antibiotics and supportive care. During his course in hospital, the patient improved and was discharged 20 days after admission, with a full recovery reported 12 weeks following initial presentation.

Tetanus is the clinical manifestation of infection with Clostridium tetani (1). The exotoxin produced by tetanus bacilli acts on the spinal cord and causes painful muscular contractions, especially of the neck and masseter 
muscles, thus the colloquial name "lockjaw" (2). More severe symptoms include respiratory problems, coma and death (2). Tetanus spores are ubiquitous in the environment and can infect any exposed wound (1). Prevention of tetanus is achieved through appropriate wound care and immunization (1).

Tetanus is rare in Canada with an average of four cases per year (range 1-10 per year) between 1990 and 2010 (3). Since the 1920s there has been a significant decrease in the number of deaths from tetanus due to the availability of vaccine and improvements in critical care $(1,2)$. The case fatality rate due to tetanus in unvaccinated persons varies significantly from $10 \%$ to over $80 \%$ with the very young and elderly being at greatest risk $(1,3,4)$.

In Canada, the routine immunization schedule consists of four doses of tetanus toxoid-containing vaccine, given at 2, 4, 6 and 12 to 23 months of age (typically at 18 months of age), with a booster dose at age 4-6 years (3). After the completion of the first three doses of tetanus toxoid, more than $99 \%$ of individuals will have evidence of a protective antibody titre (3). Although traditionally a tetanus antibody titre of $>0.01 \mathrm{IU} / \mathrm{mL}$ by mouse neutralization assay has been considered protective; some studies have suggested a higher correlate of protection, such as 0.1 $\mathrm{IU} / \mathrm{mL}$. is required (5-7). Observational studies have demonstrated the efficacy of pre- and post-wound exposure immunization regimens (3). Subsequent booster doses are recommended at 10-year intervals, although the most recent edition of the Canadian Immunization Guide indicates that new evidence on the optimal timing of booster doses is currently under review (3). Depending on the nature of the wound and prior immunization history, postexposure immunization (active and passive) may also be indicated (3).

Nevertheless, tetanus may still occur post immunization. Given the above case of tetanus with a history of a complete and documented primary series of tetanus toxoid, along with a "booster" nine years prior to presentation, a systematic review was conducted to assess the characteristics of tetanus in previously immunized individuals.

\section{Methods}

A systematic literature search was undertaken using Ovid MEDLINE(R) and EMBASE databases for articles published between 1946 and September 3, 2013. The search strategy was developed in MEDLINE using the following MESH terms: tetanus/, tetanus toxoid/, diagnosis/, diagnosis, differential/, immunization/, vaccination/. The controlled vocabulary was supplemented by the use of related keywords to increase the specificity of the search: "fully", "preexisting", "previous* “, "prior”, "presen*”, "protective”, "active”, "antibodies", immune*”, "vaccine*". The search terms were combined using Boolean operators. No limits were applied to search in MEDLINE. The search in EMBASE, after the controlled vocabulary was translated to Emtree terms, was limited to non-MEDLINE content.

Abstracts were screened for the article being written in either English or French and a diagnosis of tetanus in one or more individuals. Abstracts meeting both screening criteria were obtained for full text review. Two authors (JPH, SEW) reviewed the articles for inclusion in the review.

In order to be included in the review, the article had to describe at least one case of tetanus, the immunization history of a fully or partially immunized case and/or present the results of anti-tetanus antibodies and be written in either English or French. The formal search was supplemented by PubMed snowball searches performed on articles meeting pre-specified inclusion criteria. In addition, a review of references from each relevant article was undertaken.

Relevant data, including number of tetanus cases, age, sex, antibody titre, clinical outcome, historic tetanus toxoid immunization, including number of doses and timing were abstracted and collated (Microsoft Excel 2010, Redmond, WA). One author (JPH) abstracted the data which was reviewed for accuracy by a second author (SEW). Discrepancies (which were rare) were resolved through consensus. 
A formal quality assessment of individual articles was not undertaken. The retrieved articles included case reports, case series or surveillance reports. To the authors' knowledge, there is no validated tool for quality appraisal of these study designs. However, studies that were missing relevant data were excluded as per a priori inclusion and exclusion criteria. As this was a narrative synthesis of the literature, funnel plots and statistical assessments of heterogeneity were not appropriate measures of publication bias.

\section{Results}

Over 4000 articles were initially identified. Fifty-one unique articles were included in the review. Figure 1 summarizes the literature search results.

Figure 1: Literature search results

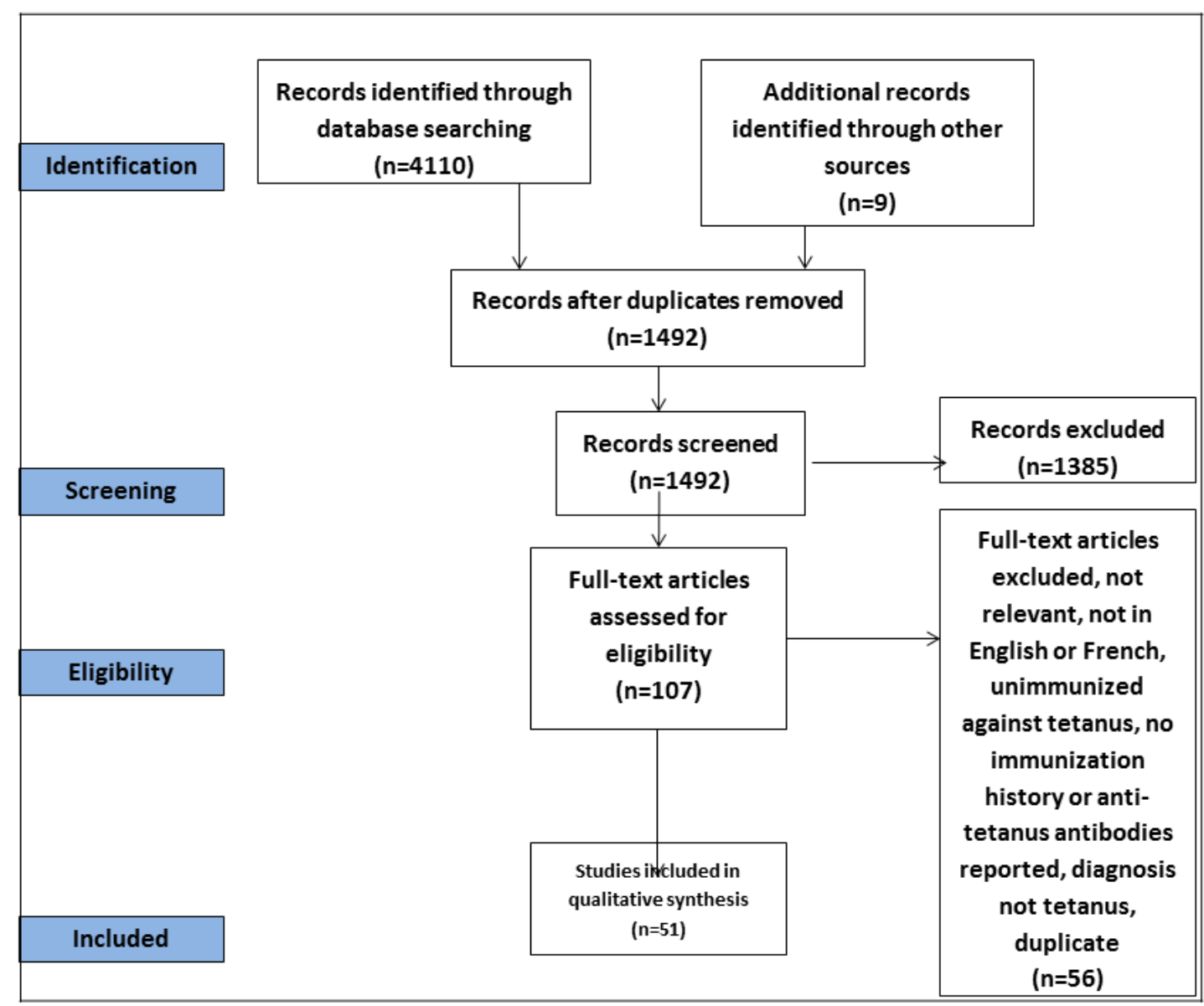

In the 51 studies that were included there were 359 cases of clinical tetanus in individuals with prior receipt of one or more doses of tetanus toxoid vaccine and/or levels of tetanus antibody titres generally considered protective (8$9)$. The majority of studies $(n=25)$ were based on data from the United States. Of 47 cases where age and sex were described, 26 (39.4\%) were male with a median age of 26 years (range 1-79 years). Fourteen cases had tetanus antibody titres drawn prior to administration of antitoxin, while the remaining 345 cases had immunization confirmed on record review. All cases of tetanus were diagnosed based on clinically compatible symptoms and signs. The isolation of Clostridium tetani was not reported in any case.

Vaccination histories of cases were reviewed within the case reports. While inclusion criteria required all cases to have received one or more doses, only $175(48.7 \%)$ reported the exact number of doses. Ninety-four cases 
( $26.2 \%$ of total cases) received three or more doses suggesting the primary series may have been completed, although it was not possible to assess the interval between doses. With respect to doses which occurred beyond early childhood and were described as "boosters" but which may or may not have been preceded by a complete primary vaccine series, 57 cases $(15.9 \%)$ received a booster dose of tetanus toxoid within the last 10 years, 54 cases $(15.0 \%)$ received a booster dose 10 or more years in the past and 248 cases $(69.1 \%)$ last received a booster at an unknown interval (or no booster was given), or the case was not eligible for a booster (e.g. based on a historic policy or age) (data not shown). As more than half of the cases did not report the number of doses of tetanus toxoid received and there were a small number of deaths $(n=30)$, it was not possible to analyze survival data by number of doses.

The high survival in published case reports suggest milder disease that is associated with better prognosis in individuals with a history of tetanus immunization $(3,4,20-23)$. This is in keeping with an attenuation of clinical severity in immunized hosts that is recognized in other vaccine-preventable diseases (24-26).

Of the 180 of $210(85.7 \%)$ cases that reported on clinical outcome survived to discharge and in cases that were followed beyond discharge, all except three $(17,27,28)$ had complete resolution of symptoms. While survival generally appeared to improve over time, $42 \%$ of studies $(n=149)$ did not report the clinical outcome so it was not possible to study survival trends as they related to other factors (e.g. systematic improvements in critical care over time and increased implementation of a 3-dose primary immunization series). The studies are summarized in

Tables 1 and 2.

Table 1: Case reports of tetanus in individuals with complete data (detailed information on tetanus immunization history or tetanus antibody and clinical outcome)

\begin{tabular}{|c|c|c|c|c|c|c|}
\hline Author / country & $\begin{array}{l}\text { Study } \\
\text { design/ } \\
\text { number of } \\
\text { cases }(\mathrm{n})\end{array}$ & $\begin{array}{l}\text { Age } \\
\text { (years) } \\
\text { and } \\
\text { sex }\end{array}$ & $\begin{array}{l}\text { Risk } \\
\text { factors } \\
\text { for } \\
\text { tetanus }\end{array}$ & $\begin{array}{l}\text { Vaccination } \\
\text { history }^{3}\end{array}$ & $\begin{array}{l}\text { Tetanus } \\
\text { antibody } \\
\text { titre at } \\
\text { diagnosis }^{4}\end{array}$ & $\begin{array}{l}\text { Patient } \\
\text { outcome }^{5}\end{array}$ \\
\hline $\begin{array}{l}\text { Abrahamian(8) / } \\
\text { United States }\end{array}$ & $\begin{array}{c}\text { Case report/ } \\
n=1\end{array}$ & $45 \mathrm{M}$ & IDU & $?$ & ++ & - \\
\hline Atabek(9)/Turkey & $\begin{array}{c}\text { Case report/ } \\
n=1\end{array}$ & $7 \mathrm{~F}$ & Laceration & ++ & $?$ & + \\
\hline $\begin{array}{l}\text { Aydin-Teke(29) / } \\
\text { Turkey }\end{array}$ & $\begin{array}{c}\text { Case report/ } \\
n=1\end{array}$ & $15 \mathrm{M}$ & Injury & ++ & $?$ & + \\
\hline $\begin{array}{l}\text { Bardenheier(22) / } \\
\text { United States }\end{array}$ & $\begin{array}{c}\text { Surveillance/ } \\
n=31\end{array}$ & $?$ & $?$ & $\begin{array}{c}+(15) \\
++(16)\end{array}$ & $?$ & $\begin{array}{c}+(30) \\
-(1) \\
\end{array}$ \\
\hline $\begin{array}{l}\text { Berger(16)/ United } \\
\text { States }\end{array}$ & $\begin{array}{l}\text { Case report/ } \\
n=1\end{array}$ & $25 \mathrm{~F}$ & IDU & $?$ & + & + \\
\hline $\begin{array}{l}\text { Boyd(30)/ Europe and } \\
\text { Africa }\end{array}$ & $\begin{array}{c}\text { Retrospective } \\
\text { surveillance/ } \\
n=16\end{array}$ & $?$ & $?$ & $+/++$ & $?$ & $\begin{array}{l}+(11) \\
-(5)\end{array}$ \\
\hline Boyer(31)/France & $\begin{array}{l}\text { Case review/ } \\
n=10\end{array}$ & $?$ & $?$ & $+/++$ & $?$ & $\begin{array}{l}+(2) \\
-(8) \\
\end{array}$ \\
\hline $\begin{array}{l}\text { Coniglione(32)/ United } \\
\text { States }\end{array}$ & $\begin{array}{c}\text { Case report/ } \\
n=1\end{array}$ & $29 \mathrm{M}$ & Injury & ++ & ++ & + \\
\hline $\begin{array}{l}\text { Crone(17)/ United } \\
\text { States }\end{array}$ & $\begin{array}{c}\text { Case report/ } \\
n=3\end{array}$ & $\begin{array}{l}29 \mathrm{M} \\
42 \mathrm{~F} \\
57 \mathrm{~F}\end{array}$ & $\begin{array}{c}? \\
\text { IDU } \\
\text { Reused } \\
\text { syringe }\end{array}$ & $\begin{array}{l}++ \\
+ \\
+\end{array}$ & $++(3)$ & $\begin{array}{c}+ \\
- \\
+(\text { deficits })\end{array}$ \\
\hline $\begin{array}{l}\text { de la } \\
\text { Chapelle(33)/France }\end{array}$ & $\begin{array}{c}\text { Case report/ } \\
n=1\end{array}$ & $52 \mathrm{M}$ & Injury, IS & $?$ & ++ & + \\
\hline $\begin{array}{l}\text { Dyce(27)/ United } \\
\text { States }\end{array}$ & $\begin{array}{l}\text { Case report/ } \\
n=1\end{array}$ & $24 \mathrm{~F}$ & Piercing & ++ & $?$ & $+($ deficits $)$ \\
\hline Faust(34)/ United & Hospital & $5 \mathrm{M}$ & $?$ & + & $?$ & + \\
\hline
\end{tabular}




\begin{tabular}{|c|c|c|c|c|c|c|}
\hline States & $\begin{array}{c}\text { surveillance/ } \\
n=1\end{array}$ & & & & & \\
\hline Fiorillo(35) / Canada & $\begin{array}{c}\text { Case report/ } \\
n=1\end{array}$ & $10 \mathrm{M}$ & Injury & ++ & ++ & + \\
\hline $\begin{array}{l}\text { Hall(36) / United } \\
\text { States }\end{array}$ & $\begin{array}{c}\text { Case report/ } \\
n=2\end{array}$ & $?$ & $?$ & $+(2)$ & $?(2)$ & $\begin{array}{l}+(1) \\
-(1)\end{array}$ \\
\hline $\begin{array}{l}\text { Hedrick(37) / United } \\
\text { States }\end{array}$ & $\begin{array}{c}\text { Case report/ } \\
n=2\end{array}$ & $\begin{array}{l}10 \mathrm{M} \\
45 \mathrm{M}\end{array}$ & $\begin{array}{c}\text { Injury } \\
?\end{array}$ & $\begin{array}{c}++ \\
+\end{array}$ & $?(2)$ & $+(2)$ \\
\hline $\begin{array}{l}\text { Hopkins (this report) / } \\
\text { Canada }\end{array}$ & $\begin{array}{l}\text { Case report/ } \\
n=1\end{array}$ & $22 \mathrm{M}$ & Injury, IS & ++ & $?$ & + \\
\hline König(10) / Germany & $\begin{array}{l}\text { Case report/ } \\
n=1\end{array}$ & $14 \mathrm{M}$ & Injury & ++ & $?$ & + \\
\hline $\begin{array}{l}\text { Livorsi(11)/ United } \\
\text { States }\end{array}$ & $\begin{array}{c}\text { Case report/ } \\
n=1\end{array}$ & $44 \mathrm{M}$ & Injury & $?$ & ++ & + \\
\hline Lodha(38) / India & $\begin{array}{c}\text { Case report/ } \\
n=2\end{array}$ & $\begin{array}{l}3 \mathrm{~F} \\
4.5 \mathrm{M}\end{array}$ & $?(2)$ & $\begin{array}{c}? \\
++\end{array}$ & $?(2)$ & $+(2)$ \\
\hline $\begin{array}{l}\text { Long(39) / United } \\
\text { States }\end{array}$ & $\begin{array}{c}\text { Surveillance/ } \\
n=6\end{array}$ & $?$ & Injury & $++(6)$ & $?$ & $\begin{array}{l}+(3) \\
-(3) \\
\end{array}$ \\
\hline $\begin{array}{l}\text { Loscalzo(40) / United } \\
\text { States }\end{array}$ & $\begin{array}{l}\text { Case report/ } \\
n=1\end{array}$ & $23 \mathrm{~F}$ & Piercing & ++ & $?$ & + \\
\hline Luisto(12) / Finland & $\begin{array}{c}\text { Retrospective } \\
\text { case series/ } \\
n=5\end{array}$ & $\begin{array}{l}5 \mathrm{M} \\
10 \mathrm{~F} \\
12 \mathrm{M} \\
13 \mathrm{~F} \\
15 \mathrm{~F}\end{array}$ & $\begin{array}{l}\text { Animal } \\
\text { bite } \\
\text { Infection } \\
\text { Injury } \\
\text { Injury } \\
\text { Burn }\end{array}$ & $\begin{array}{c}++ \\
++ \\
++ \\
++ \\
?\end{array}$ & $?(5)$ & $+(5)$ \\
\hline $\begin{array}{l}\text { Newton-John(23) / } \\
\text { Australia }\end{array}$ & $\begin{array}{c}\text { Case series/ } \\
\mathrm{n}=19\end{array}$ & $?$ & $?$ & $\begin{array}{l}++(13) \\
+(6) \\
\end{array}$ & $?$ & $\begin{array}{l}+(17) \\
-(2)\end{array}$ \\
\hline $\begin{array}{l}\text { Otero-Maldonado(28) / } \\
\text { Puerto Rico }\end{array}$ & $\begin{array}{c}\text { Case report } \\
\text { and } \\
\text { surveillance/ } \\
n=7\end{array}$ & $\begin{array}{l}67 \mathrm{M} \\
?(6)\end{array}$ & $\begin{array}{l}\text { Injury } \\
?(6)\end{array}$ & $\begin{array}{c}+ \\
?(6)\end{array}$ & $?(7)$ & $\begin{array}{l}+ \text { (deficits) } \\
+(5),-(1)\end{array}$ \\
\hline $\begin{array}{l}\text { Pascual(21) / United } \\
\text { States }\end{array}$ & $\begin{array}{l}\text { Surveillance/ } \\
n=30\end{array}$ & $?$ & $?$ & $\begin{array}{c}+(10) \\
++(20)\end{array}$ & $?(30)$ & $\begin{array}{c}+(10) \\
+(19),-(1)\end{array}$ \\
\hline $\begin{array}{l}\text { Passen(14) / United } \\
\text { States }\end{array}$ & $\begin{array}{c}\text { Case report/ } \\
n=1\end{array}$ & $35 \mathrm{M}$ & Injury & ++ & ++ & + \\
\hline Peterson(18) / Sweden & $\begin{array}{c}\text { Case report/ } \\
n=1\end{array}$ & $12 \mathrm{M}$ & Injury & ++ & ++ & + \\
\hline $\begin{array}{l}\text { Spittle(41) / New } \\
\text { Zealand }\end{array}$ & $\begin{array}{c}\text { Case report/ } \\
n=1\end{array}$ & $25 \mathrm{~F}$ & Injury & ++ & $?$ & + \\
\hline $\begin{array}{l}\text { Tiwari(4) / United } \\
\text { States }\end{array}$ & $\begin{array}{c}\text { Surveillance/ } \\
n=55\end{array}$ & $?$ & $?$ & $\begin{array}{c}+(26) \\
++(29)\end{array}$ & $?(55)$ & $\begin{array}{l}+(17),- \\
(3), ?(6) \\
+(24),- \\
(1), ?(4)\end{array}$ \\
\hline Vieria(19) / Australia & $\begin{array}{c}\text { Case report/ } \\
n=1\end{array}$ & $18 \mathrm{M}$ & Injury & ++ & $?$ & + \\
\hline
\end{tabular}

${ }^{1} \mathrm{M}$ (male), $\mathrm{F}$ (female),? (unknown/not reported)

2 ? (unknown/not reported)

$3++(3$ or more doses $),+(1$ or 2 doses $), ?$ (exact number of doses not reported)

${ }^{4}++(>0.1 \mathrm{IU} / \mathrm{ml}),+(0.01-0.09 \mathrm{IU} / \mathrm{ml}), ?=$ not measured

${ }^{5}+$ (alive at discharge), - (deceased),? (unknown/not reported)

IDU = injection drug use

IS = immunosuppression 
Table 2: Case reports of tetanus in individuals lacking complete data (detailed) information on tetanus immunization history and/or clinical outcome)

\begin{tabular}{|c|c|c|c|c|c|c|}
\hline Author/ country & $\begin{array}{c}\text { Study } \\
\text { design/ } \\
\text { number of } \\
\text { cases (n) }\end{array}$ & $\begin{array}{c}\text { Age } \\
\text { (years) } \\
\text { and sex }\end{array}$ & $\begin{array}{c}\text { Risk } \\
\text { factors for } \\
\text { tetanus }\end{array}$ & $\begin{array}{l}\text { Vaccination } \\
\text { history }^{3}\end{array}$ & $\begin{array}{c}\text { Tetanus } \\
\text { antibody } \\
\text { titre at } \\
\text { diagnosis }^{4}\end{array}$ & $\begin{array}{l}\text { Patient } \\
\text { outcome }^{5}\end{array}$ \\
\hline Bankole(42) / Nigeria & $\begin{array}{c}\text { Case } \\
\text { series/ } \\
\mathrm{n}=11\end{array}$ & $?$ & $?$ & $?$ & $?$ & $?$ \\
\hline $\begin{array}{l}\text { Beltran(43) / United } \\
\text { States }\end{array}$ & $\begin{array}{c}\text { Case } \\
\text { report/ } n=1\end{array}$ & $58 \mathrm{M}$ & Animal bite & $?$ & ++ & $?$ \\
\hline $\begin{array}{l}\text { Bunch(44) / United } \\
\text { States }\end{array}$ & $\begin{array}{c}\text { Case } \\
\text { series } / n=5\end{array}$ & $\begin{array}{l}53 \mathrm{~F} \\
59 \mathrm{~F} \\
62 \mathrm{~F} \\
65 \mathrm{~F} \\
75 \mathrm{~F}\end{array}$ & $\begin{array}{c}\text { ? } \\
\text { Injury } \\
\text { Infection } \\
\text { Laceration } \\
\text { Laceration }\end{array}$ & $?(5)$ & $?(5)$ & $+(5)$ \\
\hline $\begin{array}{l}\text { Christensen(45) / } \\
\text { United States }\end{array}$ & $\begin{array}{c}\text { Case } \\
\text { report/ } n=1\end{array}$ & $10 \mathrm{M}$ & Injury & + & $?$ & $?$ \\
\hline $\begin{array}{l}\text { Culbertson(46) / } \\
\text { United States }\end{array}$ & $\begin{array}{c}\text { Case } \\
\text { report/ } n=1\end{array}$ & $41 \mathrm{M}$ & $\begin{array}{c}\text { Burn, } \\
\text { lacerations }\end{array}$ & $?$ & $?$ & + \\
\hline deSouza(47) / India & $\begin{array}{c}\text { Case } \\
\text { control/ } n=1\end{array}$ & $?$ & $?$ & + & $?$ & $?$ \\
\hline $\begin{array}{l}\text { Earis(48) / United } \\
\text { Kingdom }\end{array}$ & $\begin{array}{c}\text { Case } \\
\text { report/ } n=1\end{array}$ & $66 \mathrm{~F}$ & $\begin{array}{l}\text { Fungating } \\
\text { tumour }\end{array}$ & $?$ & $?$ & + \\
\hline Edsall(49) / multiple & $\begin{array}{l}\text { Review of } \\
\text { previously } \\
\text { published } \\
\text { cases }^{6} / \mathrm{n}=4\end{array}$ & $?$ & $?$ & $?(4)$ & ? & $\begin{array}{l}+(3) \\
-(1)\end{array}$ \\
\hline $\begin{array}{l}\text { Ferris(50) / United } \\
\text { Kingdom }\end{array}$ & $\begin{array}{c}\text { Case } \\
\text { report/ } n=1\end{array}$ & $17 \mathrm{M}$ & Trauma & $?$ & $?$ & + \\
\hline Geeta(51) / India & $\begin{array}{c}\text { Case } \\
\text { series/ } \\
\mathrm{n}=12\end{array}$ & $\begin{array}{c}1 \mathrm{M} \\
?(11)\end{array}$ & $?$ & $\begin{array}{c}++ \\
+(11)\end{array}$ & $?$ & $?$ \\
\hline $\begin{array}{l}\text { Hahn(52) / United } \\
\text { States }\end{array}$ & $\begin{array}{c}\text { Case } \\
\text { report/ } n=1\end{array}$ & $58 \mathrm{M}$ & $?$ & $?$ & $?$ & + \\
\hline $\begin{array}{l}\text { Henderson(53) / } \\
\text { United States }\end{array}$ & $\begin{array}{c}\text { Case } \\
\text { series } / n=5\end{array}$ & $?$ & $\begin{array}{l}\text { Various } \\
\text { injuries; } \\
\text { IDU }\end{array}$ & $?$ & $?$ & $?$ \\
\hline Iqbal(54) / Pakistan & $\begin{array}{c}\text { Case } \\
\text { series/ } \\
\mathrm{n}=10\end{array}$ & $?$ & $?$ & $?$ & $?$ & $?$ \\
\hline Lee(55) / Taiwan & $\begin{array}{c}\text { Case } \\
\text { series/ } n=2\end{array}$ & $\begin{array}{l}3 ? \\
5 ?\end{array}$ & $?(2)$ & $?(2)$ & $?(2)$ & $?(2)$ \\
\hline Masthi(56) / India & $\begin{array}{c}\text { Case } \\
\text { series/ } n=2\end{array}$ & $?$ & $?$ & $?$ & ? & $?$ \\
\hline $\begin{array}{l}\text { O'Malley(13) / United } \\
\text { States }\end{array}$ & $\begin{array}{c}\text { Case } \\
\text { report/ } n=1\end{array}$ & $27 \mathrm{~F}$ & Piercing & $?$ & ++ & $?$ \\
\hline $\begin{array}{l}\text { Orwitz(57) / United } \\
\text { States }\end{array}$ & $\begin{array}{c}\text { Case } \\
\text { report/ } n=1\end{array}$ & $79 \mathrm{M}$ & Infection & $?$ & $?$ & $?$ \\
\hline $\begin{array}{l}\text { Percy(58) / United } \\
\text { States }\end{array}$ & $\begin{array}{c}\text { Case } \\
\text { series/ } n=1\end{array}$ & $?$ & $?$ & + & ? & $?$ \\
\hline $\begin{array}{l}\text { Quackenbush(59) / } \\
\text { United States }\end{array}$ & $\begin{array}{c}\text { Case } \\
\text { report } / \mathrm{n}=1\end{array}$ & $44 \mathrm{~F}$ & Injury & $?$ & $?$ & + \\
\hline Rushdy(20) / United & Surveillance & $?$ & $?$ & ? & ? & $?$ \\
\hline
\end{tabular}


${ }^{1} \mathrm{M}$ (male), F (female),? (unknown/not reported)

2 ? (unknown/not reported)

$3++(3$ or more doses $),+(1$ or 2 doses $), ?$ (exact number of doses not reported)

$4++(>0.1 \mathrm{IU} / \mathrm{ml}),+(0.01-0.09 \mathrm{IU} / \mathrm{ml}), ?=$ not measured

$5+($ alive at discharge), - (deceased),? (unknown/not reported)

${ }^{6}$ Studies described in table (p. 127). Original studies were obtained where possible (Long, Hall, Boyd, Boyer, Christensen). Remaining studies were not indexed in PubMed, MEDLINE or EMBASE. The Journal of the American Medical Association (JAMA) was contacted for the original reference list which was excluded from the published manuscript due to length, but no copy was archived. Cases summarized here are from Moss and Hedrick.

IDU = injection drug use

IS = immunosuppression

\section{Discussion}

To the authors' knowledge, this is the first systematic review which assesses the occurrence of tetanus in previously immunized individuals. Since 1946, at least 359 cases of tetanus have been described in previously immunized individuals and of those whose outcomes were reported, there was a survival rate of $85.7 \%$ with few cases reporting residual deficits at discharge. In cases that reported the number of doses of tetanus toxoid previously received by individuals, the clinical severity of disease appeared to be less compared to those who received fewer previous doses (although this could not be studied systematically due to the small number of deaths and cases symptomatic at discharge).

A previous review found a similar relationship between the number of doses and clinical severity. A review of 175 tetanus cases reported through routine surveillance between 1984 and 2000 in England and Wales found that clinical severity was greater in those with no previous history of immunization (although this did not reach statistical significance $(p=0.068))(20)$.

Potential explanations for the occurrence of clinical tetanus in the setting of past immunization could include: waning of vaccine-derived immunity; vaccine failure; the presence of an unrecognized immunodeficiency resulting in sub-optimal immune response to active vaccination; or compromised vaccine storage and handling resulting in reduced immunogenicity of the vaccine product. Alternatively, the burden of tetanus exotoxin may exceed an individual's immune response which may be additionally influenced by factors that cause immune suppression, such as chronic diseases or medications.

Limitations of this review include: the inability to assess how frequent this phenomenon is due to the lack of a denominator; potential publication bias; and incomplete data (e.g. survival). In addition, the inherent limitations of case studies and surveillance reports include: collection of source information (e.g. recall bias if self-reported, data quality and consistency if taken from databases; under-reporting or ability to capture all cases in a surveillance system); and a lack of a consistent clinical definition for tetanus in case reports created challenges in interpretation of the data.

Nonetheless, this study contributes significantly as it is possibly the first systematic review which summarizes the characteristics of tetanus in cases previously immunized with tetanus toxoid. Other strengths of this study include: the systematic methodology used to identify relevant studies; and the inclusion of articles from multiple countries, studies from 1946 through 2013 and studies in two languages.

Attenuation of disease severity in immunized hosts suggests the potential for under-reporting if the person does not present for medical care as well as the possibility of delayed diagnosis, although this was not consistently described in the included articles. This has important implications for the surveillance of vaccine-preventable diseases and clinical practice. 
Future research directions might focus on understanding the incidence of tetanus in those with previous vaccination with tetanus toxoid and whether this is due to waning immunity or vaccine failure, the optimum timing of tetanus toxoid boosters and further research into the cut-off and role of anti-tetanus antibodies in determining immunity to tetanus.

\section{Conclusions}

Tetanus is a rare, but potentially lethal disease and Clostridium tetani are ubiquitous in the environment. A completed primary vaccine series and appropriate boosters clearly do not confer protective immunity in all recipients; however the survival rate is high in those with previously documented doses of tetanus toxoid. Clinicians should maintain a high index of clinical suspicion for tetanus when the clinical symptoms suggest it, regardless of vaccination history.

\section{Acknowledgements}

The authors express their sincere thanks to Public Health Ontario Library Services, in particular Beata Pach, for assistance with the systematic search and retrieval of literature and to Dr. Shelley Deeks for her helpful comments on an earlier draft of the manuscript.

\section{Conflict of interest}

There are no conflicts of interests to declare.

\section{Funding}

No funds were received for this study

\section{References}

(1) American Public Health Association. Tetanus. In: Heymann DL, editor. Control of communicable diseases manual, 19th Ed. Washington, D. C. : American Public Health Association; 2008. 602-8.

(2) Public Health Agency of Canada. Tetanus. 2012 [updated 2012-11-23; cited 2013 2013-05-03]; http://www. phac-aspc. gc. ca/im/vpd-mev/tetanus-eng.php.

(3) Public Health Agency of Canada. Tetanus toxoid. 2012. In: Canadian Immunization Guide [Internet]. Public Health Agency of Canada. http://www. phac-aspc. gc. ca/publicat/cig-gci/p04-tet-eng.php.

(4) Tiwari T, Clark TA, Messonnier NE, Thomas CG. Tetanus surveillance - United States, 2001-2008. Morbidity and Mortality Weekly Report. 2011;60(12):365-9.

(5) Plotkin SA. Correlates of vaccine-induced immunity. Clinical Infecious Diseases. 2008;47:401-9.

(6) Plotkin SA. Correlates of protection induced by vaccination. Clinical and Vaccine Immunology. 2010;17(7):1055-65.

(7) McComb JA. The prophylactic dose of homologous tetanus antitoxin. New England Journal of Medicine. 1964;270(4):175-8.

(8) Abrahamian FM, Pollack Jr. CV, LoVecchio F, Nanda R, Carlson RW. Fatal tetanus in a drug abuser with "protective" antitetanus antibodies. Journal of Emergency Medicine. 2000;18(2):189-93.

(9) Atabek ME, Pirgon O. Tetanus in a fully immunized child. Journal of Emergency Medicine. 2005;29(3):345-6.

(10) König K, Ringe H, Dorner BG, Diers A, Uhlenberg B, Müller D, et al. Atypical tetanus in a completely immunized 14year-old boy. Pediatrics. 2007;120:e1355-8.

(11) Livorsi DJ, Eaton M, Glass J. Generalized tetanus despite prior vaccination and a protective level of anti-tetanus antibodies. American Journal of the Medical Sciences. 2010;339(2):200-1.

(12) Luisto M, livanainen M. Tetanus of immunized children. Developmental Medicine and Child Neurology. 1993;35:346-58.

(13) O'Malley CD, Smith N, Braun R, Prevots DR. Tetanus associated with body piercing. Clinical Infecious Diseases. 1998;27(5):1343-4. 
(14) Passen EL, Andersen BR. Clinical tetanus despite a "protective" level of toxin-neutralizing antibody. Journal of the American Medical Association. 1986;255(9):1171-3.

(15) Shimoni Z, Dobrousin A, Cohen J, Pitlik S. Tetanus in an immunised patient. British Medical Journal. $1996 ; 319: 1049$.

(16) Berger SA, Cherubin CE, Nelson S, Levine L. Tetanus despite preexisting antitetanus antibody. Journal of the American Medical Association. 1978;240(8):769-70.

(17) Crone NE, Reder AT. Severe tetanus in immunized patients with high anti-tetanus titers. Neurology. 1992;42:761-4.

(18) Peterson H-I. A case of tetanus in spite of active toxoid prophylaxis. Acta Chirurgica Scandinavica. 1965;129:235-7.

(19) Vieira BI, Dunne JW, Summers Q. Cephalic tetanus in an immunized patient. Medical Journal of Australia. 1986;145(Aug 4/18):156-7.

(20) Rushdy AA, White JM, Ramsay ME, Crowcroft NS. Tetanus in England and Wales, 1984-2000. Epidemiology and Infection. 2003;130:71-7.

(21) Pascual FB, McGinley EL, Zanardi LR, Cortese MM, Murphy TV. Tetanus surveillance - United States, $1998-2000$. Morbidity and Mortality Weekly Report. 2003;52(SS03):1-8.

(22) Bardenheier B, Prevots DR, Khetsuriani N, Wharton M. Tetanus surveillance - United States, 1995-1997. Morbidity and Mortality Weekly Report. 1998;47(SS-2):1-13.

(23) Newton-John HF. Tetanus in Victoria, 1957-1980. Review of 106 patients managed in one hospital. Medical Journal of Australia. 1984;140(4):194-200.

(24) van den Hoek A, Sonder GJ, Scholing M, Gijselaar DB, van Binnendijk RS. Two cases of mild IgM-negative measles in previously vaccinated adults, the Netherlands, April and July 2011. Eurosurveillance. 2011;16(48):1-3.

(25) Rota JS, Hickman CJ, Sowers SB, Rota PA, Mercader S, Bellini WJ. Two case studies of modified measles in vaccinated physicians exposed to primary measles cases: high risk of infection but low risk of transmission. Journal of Infectious Diseases. 2011;204(Suppl. 1):S559-63.

(26) Chaves SS, Zhang J, Civen R, Watson BM, Carbajal T, Parella D, et al. Varicella disease among vaccinated persons: clinical and epidemiological cases 1997-2005. Journal of Infectious Diseases. 2008;197(Suppl. 2):S127-31.

(27) Dyce O, Bruno JR, Hong D, Silverstein K, Brown MJ, Mirza N. Tongue piercing: the new "rusty nail". Head \& Neck. 2000;22(7):728-32.

(28) Otero-Maldonado M, Bosques-Rosado M, Soto-Malavé R, Deliz-Roldán B, Bertrán-Pasarell J, Vargas Otero P. Tetanus is still present in the 21st centruy: case report and review of literature. Asociación Médica de Puerto Rico. 2011;103(2):41-7.

(29) Aydin-Teke T, Bayhan GI, Afsariar CE, Oz FN, Akansel AR, Tanir G. A report of two pediatric tetanus cases. Turkish Journal of Pediatrics. 2011;53(4):437-40.

(30) Boyd JSK. Tetanus in the African and European theatres of war: 1939-1945. Lancet. 1946;1(6387):113-9.

(31) Boyer J, Corre-Hurst L, Sapin-Jaloustre H, Tissier M. Le tétanos en milieu urban. Conditions d'apparition - déductions prophylactiques. La Presse Medicale. 1953;61(34):701-3.

(32) Coniglione T, Onarecker C, Pryor T. Elevated antitoxin titers in a man with generalized tetanus. Journal of Family Practice. 1997;44(3):299-303.

(33) de La Chapelle A, Lavabre O, Pinsard M, Delamonica J, Relyveld EH. Tetanus in a renal transplant recipient exhibiting the presence of circulating antitetanus antibodies determined by ELISA. Biomedicine \& Pharmacotherapy. 2002;56(4):208-10.

(34) Faust RA, Vickers OR, Cohn I. Tetanus: 2449 cases in 68 years at a Charity Hospital. Journal of Trauma. 1976;16(9):704-12.

(35) Fiorillo L, Robinson JL. Localized tetanus in a child. Annals of Emergency Medicine. 1999;33(4):460-3.

(36) Hall WW. The U. S. Navy's war record with tetanus toxoid. Ann Intern Med. 1948;28(2):298-308.

(37) Hedrick EC. Tetanus: two cases in immunised persons. California Medicine. 1953;79(1):49-50.

(38) Lodha R, Sareen A. Tetanus in immunized children. Indian Pediatrics. 2000;37(2):223-4.

(39) Long AP. Immunization to tetanus. 20092009 Jun 1. In: Medical Science Publication No 4 [Internet]. U. S. Army Medical Department. http://history. amedd. army. mil/booksdocs/korea/recad2/ch6-6. html.

(40) Loscalzo IL, Ryan J, Loscalzo J, Sama A, Cadag S. Tetanus: a clinical diagnosis. American Journal of Emergency Medicine. 1995;13(4):488-90.

(41) Spittle BJ, Pollock M, O'Donnell TV. Tetanus occurring in spite of active immunisation. New Zealand Medical Journal. 1973;77(491):250-1. 
(42) Bankole IA, Danesi MA, Ojo OO, Okubadejo NU, Ojini FI. Characteristics and outcome of tetanus in adolescent and adult patients. Journal of the Neurological Sciences. 2012;15(323):201-4.

(43) Beltran A, Go E, Haq M, Clarke HB, Zaman M, Recco RA. A case of clinical tetanus in a patient with protective antitetanus antibody level. Southern Medical Journal. 2007;100(1):83.

(44) Bunch TJ, Thalji MK, Pellikka PA, Aksamit TR. Respiratory failure in tetanus: case report and review of a 25-year experience. Chest. 2002;122(4):1488-92.

(45) Christensen NA, Thurber DL. Clinical experience with tetanus: 91 cases. Proceedings of the Staff Meetings Mayo Clinic. 1957;32(7):146-58.

(46) Culbertson TA, Kalliainen LK, Buchele BA. Tetanus and the plastic surgeon. Annals of Plastic Surgery. 2004;53(2):1625 .

(47) deSouza CE, Karnad DR, Tilve GH. Clinical and bacteriological profile of the ear in otogenic tetanus: a case control study. Journal of Laryngology and Otology. 1992;106(12):1051-4.

(48) Earis JE, Hillis AN, Macaulay MB. Tetanus: an unusual source and site of infection. Journal of Infection. 1983;7(1):72-3.

(49) Edsall G. Specific prophylaxis of tetanus. Journal of the American Medical Association. 1959;171(4):125-35.

(50) Ferris DMS. A case of tetanus modified by previous immunization, presenting as a psychiatric condition. Nursing Times. 1968;64(34):1139-40.

(51) Geeta MG, Krishnakumar P, Mathews L. Intrathecal tetanus immunoglobulins in the management of tetanus. Indian Journal of Pediatrics. 2007;74(1):43-5.

(52) Hahn BJ, Erogul M, Sinert R. Case report of tetanus in an immunized, healthy adult and no point of entry. Journal of Emergency Medicine. 2004;27(3):257-60.

(53) Henderson SO, Mody T, Groth DE, Moore JJ, Newton E. The presentation of tetanus in an emergency department. Journal of Emergency Medicine. 1998;16(5):705-8.

(54) Iqbal S, ul Iman N, ur Rahman S, Haroon M, Zaheer Z, ur Rahman N, et al. Trends of tetanus patients in North of Pakistan. Journal of Medical Sciences (Peshawar). 2012;20(2):90-3.

(55) Lee H-C, Ko W-C, Chuang Y-C. Tetanus of the elderly. Journal of Microbiology, Immunology and Infection. 2000;33(3):191-6.

(56) Masthi NRR, Bharat G, Aswini, Chitra, Arul PPM. A clinico epidemiological study of tetanus cases admitted to epidemic disease hospital, Bangalore. Indian Journal of Public Health. 2008;52(4):210-11.

(57) Orwitz JI, Galetta SL, Teener JW. Bilateral trochlear nerve palsy and downbeat nystagmus in a patient with cephalic tetanus. Neurology. 1997;49(3):894-5.

(58) Percy AS, Kukora JS. The continuing problem of tetnaus. Surgery, Gynecology and Obstetrics. 1985;160(4):307-12.

(59) Quackenbush P, Tuorinsky S, Rabb R. Tetanus diagnosis sometimes elusive. Nurse Practitioner. 2003;28(11):50-3.

(60) Srigley JA, Haider S, Johnstone J. A lethal case of generalized tetanus. Canadian Medical Association Journal. 2011;183(9):1045-48. 